\title{
Affirmative Action in the Western Borderlands of the Late Russian Empire?
}

\section{Darius Staliūnas}

One of the main objects of a comparative analysis of empires is the ways in which the imperial center controls its peripheries, first of all, its elites, who are culturally different from the empire's core. There can be various means of control: cooperation and the coopting of periphery elites, integration with elements of acculturation or even assimilation, in some situations even extermination or expulsion, or the divide et impera policy. ${ }^{1}$ When historians write about nineteenth-century empires that applied a "divide and rule" policy in Europe, they usually have in mind the situation in the Habsburg Empire (the Austro-Hungarian Monarchy from 1867). Scholarly literature suggests that in the Habsburg monarchy, especially its Austrian part, the imperial authorities did not try to, and would not have been able to, assimilate non-dominant ethnic groups; thus it was forced to employ a policy of balance, compromises, and divide et impera. ${ }^{2}$

In recent years, historians have increasingly often seen the application of a divide et impera policy in Imperial Russian policy in the western borderlands. Sometimes these policy methods are discussed in general terms, as if they were applied almost universally across the empire's peripheries. For example, Japanese historian Kimitaka Matsuzato claimed that the total assimilation of non-Russians in one or another region was generally impossible. "The de-Polonization of the western provinces of Imperial Russia could not have been implemented without the protectionism of Ukrainian, Belarusian, and Lithuanian peasants (sometimes even the intelligentsia). The same may be said about relations between Baltic Germans and the Latvians and Estonians who were their subjects. That is why the universal harshening of national policy was simply impossible." 3 Matsuzato believes that on the peripheries of the Russian Empire, where it faced a strong disloyal national group (the Poles in the Western Region), it followed a consistent strategy. He alleges that

For helpful comments I would like to thank three anonymous reviewers, as well as Vladimir Levin, Karsten Brüggemann, Jussi Jalonen, Alexander Semyonov, Anton Kotenko, and Johannes Remy.

1. Andreas Kappeler, "Tsentr i elity periferii v gabsburgskoi, rossiiskoi i osmanskoi imperiakh (1700-1918)," Ab Imperio 2 (2007): 17-58. See also Valerie A. Kivelson and Ronald Grigor Suny, Russia's Empires (New York, 2017), 2-5.

2. Stefan Berger and Alexei Miller, "Introduction," in Nationalizing Empires, Stefan Berger and Alexei Miller, eds., (Budapest, 2014), 23.

3. Kimitaka Matsuzato, "General-gubernatorstva v Rossiiskoi imperii: Ot etnicheskogo k prostranstvennomu podkhodu," in Novaia imperskaia istoriia postsovetskogo prostranstva, ed. by Il'ia Gerasimov et. al. (Kazan, 2004), 427-458, quotation from 429. 
the Russians carried out "a policy of ethnic Bonapartism" here, that is, they tried to counterweight their most important enemies in a given region with other non-dominant national groups. The governor-generals who were sent to such lands were prepared to implement a divide and rule policy. ${ }^{4}$ Stefan Berger and Alexei Miller are somewhat more cautious, but in principle present a very similar thesis: "In the Western borderland of the Romanov Empire the authorities supported Lithuanian nationalism (and sometimes even Little Russian and White Russian regionalisms) in the hope of undermining challenges from Polish nationalism, who claimed the territory of the Grand Duchy of Lithuania. Since 1870 a similar tactic was pursued vis-à-vis Latvian and Estonian nationalisms in order to counterbalance German nationalist claims over the Baltic provinces. In Finland the empire supported the Finnish movement at the expense of Swedish elites." ${ }^{5}$ Other historians claim that such a policy was applied to specific non-dominant ethnic groups, for example, that the Lithuanian national movement "enjoyed certain advantages" compared to the Poles. ${ }^{6}$ The problem with the earlier scholarship is that, as a rule, researchers tend not to explain how they understand the policy of divide et impera, and thus the reader is left to formulate his own definition. ${ }^{7}$ It can be presumed that many understand this terminology in the same way as it is used further in this article, whereas for others it is a rather vague concept used in explaining situations when the tsarist government was implementing certain measures against local non-Russian elites (Poles in the western provinces or Baltic Germans in the Baltic provinces), and described its own policy as a support for other national groups (Latvians, Estonians, and Lithuanians). Here I am going to argue that such an approach, when the aims of imperial policy are revealed through the analysis of the rhetoric of the officials, could be rather misleading.

This article presents an attempt to explain whether the Russian government did use divide et impera methods in the western borderlands of its empire. The answer to this question is important in trying to clarify the character of the Romanov Empire's nationality policy: to what extent was it determined by an "imperial mentality," where the most important aim was

4. Ibid.

5. Berger and Miller, "Introduction," 23. Similar but more general ideas could be found in Kappeler's texts, see Kappeler, “Tsentr i elity periferii," 45-46.

6. Timothy Snyder, The Reconstruction of Nations: Poland, Ukraine, Lithuania, Belarus, 1569-1999 (New Haven, 2003), 45, 49; Egidijus Motieka, Didysis Vilniaus seimas (Vilnius, 1996), 248; Rimantas Miknys, "Lietuvos Didžiosios Kunigaikštijos valstybingumo tradicija lietuvių tautinio judejjimo politinèje programoje (teorinis ir praktinis aspektai)," in Alfredas Bumblauskas and Grigorijus Potašenko, eds., Lietuvos Didžiosios Kunigaikštijos tradicija ir tautiniai naratyvai, (Vilnius, 2009), 137. See also: Linas Venclauskas, "Modern Lithuanian Identity: Transformations and Continuity," in Steven M. Hoffman and Renee Buhr, eds., Lithuanian and Belarusian National Identity in the Context of European Integration (Kaunas, 2013), 60.

7. As a definition, the term "divide et impera" has still not acquired general scholarly consensus, like, for example, the term Russification. Starting with the path-breaking book by Edward Thaden (Edward C. Thaden, Russia's Western Borderlands, 1710-1870 [Princeton, 1984]), researchers, as a rule, tend to explain what they mean by Russification or use other analytical tools. 
to ensure the loyalty of its subjects, and to what extent was it a means for culturally homogenizing the peripheries of its empire to the maximum possible degree. Basing my study predominantly on an analysis of imperial policy concerning Lithuanians, I shall try to prove that apart from a couple of cases, there were no more situations, let alone a consistent policy, where the imperial government would have supported Lithuanian cultural development. More generally, this kind of policy was in principle not applied on its western periphery regarding other non-dominant ethnic groups either. I argue that for most of the nineteenth though the beginning of the twentieth centuries, the imperial government was seeking acculturation or even assimilation of nonRussian ethnicities rather than strengthening their national cultures.

Organized in chronological order, this article first discusses the challenges that the imperial government faced in mid-nineteenth century; later periods are covered in the subsequent sections. First, the most important ideas and plans by tsarist officials to use divide and rule methods are analyzed, and then the outcome of these debates are presented. ${ }^{8}$

In this article, divide and rule policy is understood as actions that are consciously adopted in order to weaken some national groups while supporting the strengthening of others (usually the weaker ones), rather than seeking their assimilation. ${ }^{9}$ If the imperial government declared its will to protect the Belarusians and Ukrainians from the Poles, yet considered these two ethnic groups part of the Russian nation, then this is more likely to be a policy of assimilation, but not actions based of the logic of divide et impera, regardless of the rhetoric used by bureaucrats. Nor does this article consider the kind of policy where the imperial government sought to create more or less equal conditions for various non-dominant ethnic groups to use their "native" languages, or to establish various organizations, as one that could be described as resorting to divide and rule methods. Of course, sometimes the Russian government's actions against periphery elites (Baltic Germans, Poles), like some all-imperial reforms aiming at the modernization of the state (for example, the introduction of self-government in cities), were beneficial for various non-dominant ethnic groups, but that is not the same as a conscious policy of affirmative action.

\section{Before the Abolition of Serfdom}

After quelling the uprising of 1830-31, the Russian government introduced a whole array of measures on the western periphery of its empire that were directed against Congress Poland's political, cultural, and economic selfgovernment and the influence of Poles in the so-called "returned provinces"

8. Specialists might find some episodes on mid-nineteenth century in this article as summarizing earlier scholarship, but that was unavoidable in order to show all the important contexts when a policy of divide et impera was discussed among the bureaucrats.

9. On the analytical categories of acculturation, assimilation and integration see Benjamin Nathans, Beyond the Pale: The Jewish Encounter with Late Imperial Russia (Berkeley, 2002), 11. 
(the lands of the former Grand Duchy of Lithuania and right-bank Ukraine). ${ }^{10}$ A more consistent way of thinking about using the "peasant" nations as a counterweight against the Poles did not exist, however, if only because the majority of peasants were serfs, and thus did not feature in the political discourse. When looking at the anti-Polish political context, as in the case of Dmitrii Bibikov, the governor-general of Kiev (1837-1852), who was known for his anti-Polish measures, if the economic well-being of these "peasants" was indeed a government priority, and efforts were made to protect them from Polonization, then it was because those Ukrainian peasants were considered an integral part of the tripartite Russian nation. ${ }^{11} \mathrm{~A}$ rare exception in this case was the so-called "pupils" case in Kovna province in 1852-54. ${ }^{12}$

At the beginning of 1852, Emperor Nicholas I showed concern for the "Žemaitijan" [Samogitian] students at the Telšiai Catholic Theological Seminary, who "having nothing in common with Poles except for their faith, become infected with the Polish spirit when they receive their primary education together with Polish students." ${ }^{13}$ And so began a correspondence lasting several years between St. Petersburg, Vil'na and Kovna. The above mentioned Bibikov, now Minister of Internal Affairs (1852-55), supported the idea that Samogitians and Poles should be educated separately, so that "Samogitian peasants" would not come under the influence of the Poles, and that it would not be difficult to separate them based on their estate, as the Poles were nobles while the majority of those from the other estates were Samogitians; and if there were any nobles of Samogitian origin, then they had already "assimilated with the Poles" long ago. Thus, the conclusion of the minister of internal affairs was that two types of schools could be established, one for the nobility and one for the remaining estates, thereby resolving the problem. ${ }^{14}$ Meanwhile, other officials involved in this discussion asserted that this kind of segregation would not only be impos-

10. Egidijus Aleksandravičius and Antanas Kulakauskas, Carų valdžioje. XIX amžiaus Lietuva (Vilnius, 1996), 69-78; Jörg Ganzenmüller, Russische Staatsgewalt und Polnischer Adel: Elitenintegration und Staatsausbau im Westen des Zarenreiches (1772-1850) (Köln, 2013). The imperial government usually considered all the Catholic nobility and city dwellers from these lands to be Poles.

11. Daniel Bevois, Gordiev uzel Rossiiskoi imperii: Vlast', shliakhta i narod v Pravoberezhnoi Ukraine (1793-1914) (Moscow, 2011), 329-39.

12. See files at Lietuvos valstybès istorijos archyvas (LVIA), fondas (f.) 378, Politinis skyrius (PS), 1852, byla (b.) 52 (Po Vysochaishemu poveleniiu o proiskhozhdenii vospitannikov tel'shevskoi Rimsko-katolicheskoi Seminarii); Rossiiskii gosudarstvennyj istoricheskii arkhiv (RGIA), fond (f.) 733, opis' (op.) 62, delo (d.) 1224 (O vospitanii Zhmudskogo iunoshestva w srednikh uchebnykh zavedeniakh Vilenskogo Uchebnogo okruga); Meilè Lukšienė, Lietuvos švietimo istorijos bruožai XIX a. pirmojoje pusèje (Kaunas, 1970), 222-25; Egidijus Aleksandravičius, "Tautinio identiteto link: 1852-1854 m. "mokinių byla," Kultūros barai 7-8 (1990): 96-99; Leszek Zasztowt, Kresy 1832-1864. Szkolnictwo na ziemiach Litewskich i Ruskich dawnej Rzeczypospolitej (Warsaw, 1997), 247-49.

13. RGIA, f. 733, op. 62, d. 1224, 1.1 (Official letter from the minister of internal affairs to the minister of education, February 25, 1852). Samogitians (Žematijans) is a subgroup of Lithuanians identified by a different dialect or regional criterion (those who inhabited the territory of the former Duchy of Samogitia).

14. RGIA, f. 733, op. 62, d. 1224, 1. 27-32 (Official letter from the minister of internal affairs to the minister of education, December 10, 1852). 
sible but even harmful. It would be impossible because members of the nobility dominated the seminary, while "nobles of Samogitian origin" were in effect the same "Poles," as was illustrated in the uprising of 1830-31. And this kind of segregation would be detrimental, because such measures could "remind the population of this land that some among them are Poles, while others are Lithuanians," and that generally "any measure denoting the division of the population in the Western Region according to tribes [po plemenam] could hardly comply with the government's aforementioned aims, as this land, being under the jurisdiction of the Russian ruler, must be related to Russia without any tribal differences." 15 Thus, the decision was made in St. Petersburg that the existing policy had to continue whereby the goal in educational institutions was to strengthen "the Russian elements and educate the youth as true subjects of Russia, irrespective of their different tribal origins."16 Unsurprisingly this discussion ended without any changes in imperial nationality policy. It was still too early to perceive Lithuanian or any other serfs as potential political actors. In parallel to that, the early 1850 s was politically a relatively calm period without any bigger challenges from the borderland elites; therefore, there was no need for any audacious experiments. A new situation unfolded during the epoch of the Great Reforms.

\section{Imperial Government and the Polish Threat around 1863}

After the accession of Alexander II (1855), the so-called Great Reforms that were to modernize the Romanov Empire started. The abolition of serfdom was one part of this policy, which, according to the historian Mikhail Dolbilov, became a fundamental impulse for the formation of a Russian nationalist discourse. ${ }^{17}$ At the same time, discussions about educational reform, including primary education, started among the bureaucracy. Public life was liberalized not only in central Russia, but on the empire's borderlands as well, which allowed the Kingdom of Poland and the Western Region's nobility to take various social initiatives, including demanding ever greater

15. RGIA, f. 733, op. 62, d. 1224, 1. 10-13, 19-22, 72-75, 85-86, 88-89, quotations from 85-86, 89 (Reports from the Vil'na governor general to the minister of education, June 15 , 1852 and November 27, 1853; Official letter from the minister of education to his deputy minister, July 5, 1852; official letter from the minister of education to the minister of internal affairs, December 19, 1853; report from the superviser of the Vil'na educational district to the minister of internal affairs, January 29, 1854). I should add that in the beginning, there was some miscommunication between the officials: sometimes "Samogitians" were understood as being all ethnic Lithuanians, in other cases, as just one of the Lithuanian ethnic groups.

16. RGIA, f. 733, op. 62, d. 1224, 1. 107-15, quotation from 1.115 (Document signed by the Minister of Education "On the elimination of joint education of the Polish and Samogitian youth," with the emperor's resolution, "I agree”).

17. Mikhail Dolbilov, "The Emancipation Reform of 1861 in Russia and the Nationalism of Imperial Bureaucracy," in Hayashi Tadayuki, ed., Construction and Deconstruction of National Histories in Slavic Eurasia (Sapporo, 2003), 205-35; Zapadnye okrainy Rossiiskoi imperii, Mikhail Dolbilov and Alexei Miller, eds., (Moscow, 2006), 139-40. 
concessions from the government in culture, education, and economics. ${ }^{18}$ These demands made by the Poles managed to convince a sizeable portion of the empire's political and intellectual elite as early as the early 1860 s that a compromise with the Poles could not be reached, and that other integration policy measures had to be devised..$^{19}$ Combining all the circumstances that have just been listed, we should not be surprised by the fact that some members of the ruling elite turned to the peasants as a political factor that could become a counterweight to the Poles. As Vladimir Nazimov, the governor-general of Vil'na (1855-63), who later was depicted by the Russifiers as weak, liberal, and a polonophile, wrote that the Western Region "is a point of argument, and it can only be solved by the people [narod]." ${ }^{20}$ As in the quote from Nazimov, the people from the Western Region were often conceptualized as a composite part of the Russian nation, which had to be educated and protected from Polonization, and then they could make a weighty contribution to becoming not only an integral part of the Russian Empire, but part of Russian "national territory."21

Even though at the beginning of 1862 Nazimov had recommended starting a magazine in the Belarusian dialect, in that same document he synonymously referred to the language as Russian. ${ }^{22}$ Meanwhile, subsequent recommendations from the Vil'na governor-general only mentioned the Russian language. ${ }^{23}$ In other words, he was prepared to use even the Belarusian dialect in the process of nationalizing the masses, yet treated it as a composite part of the Russian language, which is why his recommendations did not offer any ideas about some kind of support for Belarusians as a national group distinct from Russians.

Regarding the Lithuanians, Vil'na officials did not doubt their ethnocultural distinctiveness from the Russians; so, wanting to protect them from the Poles, they suggested establishing schools where Lithuanian was the

18. At that time, the Western Region referred to the nine provinces of the former Grand Duchy of Lithuania and Right-bank Ukraine-Vil'na, Kovna, Grodna, Minsk, Vitebsk, Mogiliev, Kiev, Volhynia and Podolia.

19. For more details, see Henryk Głębocki, Fatalna sprawa. Kwestia polska w rosyjskiej myśli politycznej (1856-1866) (Kraków, 2000).

20. RGIA, f. 1267, op. 1, d. 11, 1. 34 (Report from the Vil'na governor general to Alexander II with a resolution dated August 27, 1862). Like all other Russian officials who held the position of the Vil'na governor-general, Nazimov started his career in the military, however, unlike the other in the late 1830s, he became a mentor for the future emperor Alexander II. His arrival in Vil'na in 1855 was warmly welcomed by the local elite, who still remembered how Nazimov, acting as the chairman of the temporary Commission in 1841 , came to the conclusion that there was no wide-ranging conspiracy against the government, contrary to the local officials who tried to prove otherwise. At first Nazimov was in good relations with the local elite, but the situation changed in the early 1860s when the Poles started to make greater demands.

21. For more on these categories, see Alexei Miller, The Romanov Empire and Nationalism: Essays in the Methodology of Historical Research (Budapest, 2008), 163.

22. LVIA, f. 567, ap. 4, b. 915, lapas (1.) 8 (Report from the Vil'na governor general to the minister of education, June 15, 1862).

23. RGIA, f. 1267, op. 1, d. 11, 1. 34 (Report from the Vil'na governor general). 
language of instruction, and that a magazine be published in the language. ${ }^{24}$ In August 1862, Nazimov recommended that the government declare "... to establish Russian schools where Russians predominate, to allow students to learn in Lithuanian and in the Samogitian dialect where Lithuanians and Samogitians predominate, and where Poles make up the majority of the population, to teach students in Polish." 25 These recommendations sensu stricto were not held to be any kind of special support for non-Russians, since the Vil'na governor-general in effect suggested equal treatment for all the nondominant ethnic groups: there were no intentions about protectionism for Lithuanians, or discrimination against the Poles, for example. Later, in April 1863, we can notice elements of the divide and rule policy in the recommendations sent to St. Petersburg by Alexander Shirinskii-Shikhmatov, the chief of the Vil'na Educational District (1861-64). ${ }^{26}$ This official suggested eliminating the Polish language as a subject taught at gymnasiums. Furthermore, where ethnic Lithuanians made up the majority of the population, Lithuanian should be taught as a subject in gymnasiums, pre-gymnasiums, and district schools, "thereby elevating the Samogitian element which is completely unopposed to the government, and which would gradually push out the Polish [element]."27 This particular recommendation illustrates clearly the will to promote the Lithuanians at the expense of the Poles.

Similar recommendations of imperial policy matured not only in the Western Region, but in the empire's capital as well, and it could be that these initiatives were related. ${ }^{28}$ At the beginning of 1862 , the emperor was handed a program by a group of influential bureaucrats and Slavophiles, headed by Alexander Gil'ferding, regarding nationality policy in the Western Region, containing recommendations that were significantly more radical than those made by Nazimov. ${ }^{29}$ In that program, suggestions were made for the government to attract the Little Russians (Malorossy), Belarusians, and Lithuanians to its side, thereby reducing the influence of the Poles. More specifically, the program sought to establish as many primary schools as possible where the Lithuanian, Belarusian, and Malorossian languages could be "introduced"; to publish as many textbooks and religious books in "these dialects" as possible; to teach these "dialects" in secondary schools and in higher education; to encourage the clergy (no specific confession was stated) to use "local languages" as widely as possible; to publish government decrees in

24. RGIA, f. 1282, op. 2, d. 334, 1. 11-14 (Report from the Vil'na governor general to the Alexander II with a resolution, February 14, 1862).

25. RGIA, f. 1267, op. 1, d.11, 1. 34 (Report from the Vil'na governor general).

26. After spending some time in the military, Shirinskii-Skikhmatov continued his career in different institutions related to the Ministry of Education, even rising to the position of Deputy Minister (1874-80). In line with his proposals regarding the Lithuanian language, he also favored the usage of Belarusian dialects in order to isolate Belarusian Catholics from the Poles.

27. LVIA, f. 567, ap. 21, b. 15, 1. 22 (Secret report from the chief of the Vil'na Educational district to the minister of education, April 19, 1863).

28. For more on this see Darius Staliūnas, "Between Russification and Divide and Rule: Russian Nationality Policy in the Western Borderlands in the Mid-19th Century," Jahrbücher für Geschichte Osteuropas 3 (2007): 357-373.

29. For more on Gil'ferding's attitudes towards the Lithuanians see the next section. 
the "Lithuanian language," and "if the need arises, also in the Malorossy and Belarusian dialects"; to publish articles in the "local languages" in official provincial newspapers, including an insert in Lithuanian that would be added to the official newspaper already produced in Vil'na (reference is made here to the official newspaper Vilenskii vestnik). ${ }^{30}$ Even though this program received the sound approval of the emperor, however, it was rejected by the governor-generals of Vil'na and Kiev, and more importantly, not even a year had passed in the lands of the former Polish-Lithuanian state before the uprising began.

Once the rebellion was under way, the above-mentioned group of bureaucrats and Slavophiles tried to present their vision for policy in the Western Region, albeit, a quite severely edited version. Now they were asking for permission to establish a Western Russia Society, which was to serve as a center for coordinating national policy. ${ }^{31}$ This time, when speaking about eastern Slavs, it was highlighted clearly that the Society would ensure "the fostering of the Russian national spirit," thus the use of "local dialects" was foreseen only at the primary school level, and then only because students would understand the necessity of learning "the Great Russian language." It was also acknowledged, however, that Lithuanians were not Russians, and that the land between the Rivers Nemunas and Dvina could be "grabbed from the hands of the Polish nobility" only if "the Lithuanian nation wakes up and develops." 32 If we look at some specific recommendations, however, we will notice that their proposed support for the Lithuanians was significantly less than what was mentioned in their program in 1862. This time, the publication of textbooks in local dialects would take place "only if there was a need," and that the Society would see to the publication of Orthodox religious books in Lithuania so that Orthodox Lithuanians would not come under the influence of the Catholic clergy. ${ }^{33}$ In other words, these recommendations sought to protect the peasants from Polonization, but no policy of affirmative action was planned.

The tsar had these recommendations sent for deliberation to the Western Committee, which was founded in late 1862 in St. Petersburg, but there are no signs that the Committee ever considered the proposals. Mikhail Murav'ev, the new governor-general (1863-65) who arrived in Vil'na in May 1863, had no need for any recommendations, nor did he need a society of this kind: the governor-general was to direct the region's Russification, and control everything himself. ${ }^{34} \mathrm{~A}$ composite part of the new policy was the introduc-

30. RGIA, f. 940, op. 1, d. 3, 1.3-41.

31. RGIA, f. 940, op. 1, d. 4, 1. 1-40, 87-100, 111-15.

32. RGIA, f. 940, op. 1, d. 4, 1. 100.

33. We do not have reliable national statistics for this period, but the information we do have lets us claim that the number of Orthodox believers who would have identified themselves as Lithuanians was quite small.

34. Murav'ev's task was not only to suppress the uprising, but also to implement a new nationality policy that would make a new uprising impossible. Usually this policy is described as Russification. On Murav'ev's Russification policy, see: Vytautas Merkys, Knygnešiu laikai 1864-1904 (Vilnius, 1994); Theodore R. Weeks, Nation and State in Late Imperial Russia: Nationalism and Russification on the Western Frontier 1863-1914 (De Kalb, 2008); Witold Rodkiewicz, Russian Nationality Policy in the Western Provinces 
tion of the Cyrillic script and the banning of the Latin and Gothic alphabets in Lithuanian writing, which some researchers consider a "de-Polonization" measure. The goal was thus to protect Lithuanians from Polonization without turning them into Russians, without assimilating them as such. ${ }^{35}$

\section{Introduction of Cyrillic into Lithuanian Writing as a Policy for Supporting Lithuanians?}

One of those behind changing the alphabet to be used was the aforementioned Gil'ferding, an influential Slavophile, who after 1863 prepared projects for reforming the Kingdom of Poland, including the field of education. Gil'ferding suggested making Lithuanians loyal subjects of the empire and protecting them from Polish influence. He recommended that children be educated in Lithuanian at primary school, teaching the language as a subject in secondary schools, and establishing Lithuanian language departments at universities. ${ }^{36}$ At first, it seemed that the government would implement this policy in the Northwest Region. In the first few years, it was not only tsarist officials who participated in the experiment, but even some of the Lithuanian intelligentsia, who tried to create a new alphabet for Lithuanian based on Cyrillic, including adapting Cyrillic to produce the necessary sounds in the Lithuanian language, as far as it was possible. ${ }^{37}$ As we shall see later, however, this policy was short-lived. Some elements of the policy recommended by Gil' ferding were implemented in the Kingdom of Poland, where Lithuanian was taught as a subject not only in primary schools but at the secondary school level as well. This was also true in the teacher training colleges, with special scholarships being offered to Lithuanians to study at Russian universities in the 1860s. However, of all these measures, only the scholarships can be counted as an element of the divide et impera policy. Meanwhile, the status of the Lithuanian language in the Vistula region's schools was by no means exceptional: it was generally the same as for the Polish language in those places of the kingdom where Poles made up the student body, only unlike the Poles, the Lithuanians could not use the Latin alphabet until 1904. ${ }^{38}$

of the Empire (1863-1905) (Liublin, 1998); Anna Komzolova, Politika samoderzhaviia $v$ Severo-Zapadnom krae v epokhu Velikikh reform (Moscow, 2005); Darius Staliūnas, Making Russians: Meaning and Practice of Russification in Lithuania and Belarus after 1863 (Amsterdam, 2007); Mikhail Dolbilov, Russkii krai, chuzhaia vera: Etnokonfessional'naia politika imperii v Litve i Belorussii pri Aleksandre II (Moscow, 2010).

35. Alexey Miller, Imperiia Romanovykh i natsionalizm. Esse po metodologii istoricheskogo issledovaniia (Moscow, 2006), 67, 89, 92; Tomas Balkelis, The Making of Modern Lithuania (London, 2009), 5.

36. Aleksandr Gil'ferding, "Neskol'ko zamechanii o litovskom i zhmudskom plemeni," in S. Sholkovich, ed., Sbornik statei raz'iasniaiushchikh pol'skoe delo po otnosheniiu k Zapadnoi Rossii (Vilnius, 1885), 123. The same ideas: "Pol'skii vopros," in Sobranie sochinenii A. Gil' ferdinga, vol. 2: Stat'i po sovremennym voprosam slavianskim (St. Petersburg, 1868), 330.

37. Giedrius Subačius, "Lietuviška ir rusiška lietuviškų spaudinių kirilika 1864-1866 metais,” in Darius Staliūnas, ed., Raidžiu draudimo metai (Vilnius, 2004), 139-73.

38. The introduction of Cyrillic in Polish writing only lasted briefly: Maria Strycharska-Brzezina, Polskojęzyczne podręczniki dla klasy i szkoty elementarnej $w$ Królewstwie Polskim drukowane grażdanką (Kraków, 2006). 
The fact that the imperial government offered scholarships to Lithuanians from the Suwałki province and tolerated certain functions of the Lithuanian language in schools in the province, yet did nothing like it in the Northwest Region, was related to the mental map of the officials: the Vistula region was only part of the Romanov Empire, whereas for the empire's officials, a larger portion, or perhaps even the entire northwest region, was seen not only as part of the empire, but as the Russians' national territory as well. ${ }^{39}$

Thus, it comes as no surprise that the introduction of Cyrillic script in the Northwest Region went hand-in-hand with the complete elimination of Lithuanian from the public sphere, where even primary school children had all their subjects taught in Russian. Therefore, in the Northwest Region, the imperial government aimed at the acculturation of Lithuanians, which was to be followed by assimilation..$^{40}$ Also, the imperial government did not try very seriously to accustom Lithuanians to reading Lithuanian books rewritten in Cyrillic. During the entire period when these books were published until 1904, only fifty-five titles ever came out, and if we count variations on titles, the number was a little over sixty. ${ }^{41}$ From the beginning of the 1870s, not only was religious literature in Cyrillic stopped, but also calendars for both Lithuanians and Latvians. ${ }^{42}$ As far as the empire's officials were concerned, Lithuanian writing in Cyrillic was just an auxiliary measure in making Lithuanians get used to seeing publications in Russian.

At the same time, books in Polish using the traditional Latin alphabet continued to be published throughout the second half of the nineteenth and the early twentieth centuries: in some years, only a handful of such books were published in Vil'na, although in 1873 as many as forty-one titles came out. ${ }^{43}$ Polish bookshops were also allowed to remain open, and contained many Polish books that had been published elsewhere. Therefore, in the Western Region, Polish culture was in a significantly more favorable situation than Lithuanian culture. Hence, this policy of the Cyrillization of Lithuanian writings can hardly be called a policy of divide et impera. Not only peasants (Lithuanians, Belarusians, and Ukrainians) but also Jews were mentioned in the deliberations of the empire's officials from the early 1860 s as a potential counterweight to the Poles.

39. One of the indications of the concept that a certain area was part of Russian "national territory," and not just of the empire, was its identification as Rus' (be it Western, Northwest, or Lithuanian). The term Rus', as we know, was used to describe a historically-formed, ethnically and confessionally homogeneous East Slavic territory: Darius Staliūnas, "Poland or Russia? Lithuania on the Russian Mental Map," in Darius Staliūnas, ed., Spatial Concepts of Lithuania in the Long Nineteenth Century (Boston, 2016), 23-95.

40. Staliūnas, Making Russians, 233-82.

41. Vytautas Merkys, "Lietuvių draudžiamosios spaudos ir tautinès tapatybès sąsajos,” Knygotyra 44 (2005): 11.

42. The imperial government introduced Cyrillic in Latvian writing in Latgala (i.e., in the Vitebsk province, which, as already mentioned, was part of the Western Region), but not in the Baltic provinces.

43. Andrzej Romanowski, Pozytywizm na Litwie: Polskie życie na ziemiach litewskobiałorusko-inflianckich (Kraków, 2003), 126. 


\section{Jews as a Counterbalance against the Poles?}

In 1862 Aleksandr Wielopolski, a Polish aristocrat in the service of the empire, implemented a whole swathe of reforms in the Kingdom of Poland that removed restrictions imposed on Jews. Even then, these reforms were seen differently in different contexts. Some senior bureaucrats thought that Jews could become a counterweight to the Poles, while others saw danger in that the reforms would reduce the division between Poles and Jews, and turn the latter into Poles of the Mosaic Confession. Wielopolski's arguments that the reforms would benefit the kingdom's economic development ultimately impelled Emperor Alexander II to enact their implementation. ${ }^{44}$ Elements of the divide and rule policy are visible here only if the term is understood in the broadest sense. As we have seen, members of the empire's ruling elite saw their aim and possible outcomes differently. Finally, it was these reforms suggested by Wielopolski that eliminated discrimination against Jews, yet they did not grant them any privileges if we compare them to the situation of the Poles in the kingdom.

The Jews received much less lenience in the Western Region, even though at the beginning of the 1860s, numerous officials from this region did try to draw St. Petersburg's attention to the Jews, with the intention of bringing them on its side. ${ }^{45}$ But all these discussions came to an end with the outbreak of the 1863-64 uprising. Afterwards, Jews ended up basically in the same position as Poles in the officials' "hierarchy of enemies": officials were afraid that an economically stronger Jewish population would only "exploit" the peasants further, the majority of whom in the Western Region were taken as being Russians, as mentioned. In the Kingdom of Poland, there were not so many peasants requiring protection from the empire. Thus, it is not surprising that after the 1863-64 uprising, the government introduced various measures that, on one hand, protected Russians (and sometimes Baltic Germans), and on the other, discriminated not only against Poles but against Jews as well. ${ }^{46}$

By the end of the nineteenth century, many tsarist officials realized that the so-called Russification policy failed in many respects. The strengthening nationalisms of many non-dominant ethnic groups presented a new reality, created new challenges for the imperial regime, and therefore some of the imperial officials once again tried to consider implementing methods of the divide and rule policy.

\section{New Challenges in the Late Imperial Period}

At the beginning of the twentieth century, officials of the empire came face to face with another reality. Whereas in the mid-nineteenth century, Lithuanians 41-58.

44. John D. Klier, “Why Were Russian Jews not Keisertreu?” Ab Imperio 4 (2003):

45. For more on this see Darius Staliūnas, "Changes in the Political Situation and the 'Jewish Question' in the Lithuanian Gubernias of the Russian Empire (1855-April 1863)," in Alvydas Nikžentaitis, Stefan Schreiner, and Darius Staliūnas, eds., The Vanished World of Lithuanian Jews (Amsterdam, 2004), 21-43.

46. For more on the "Jewish Question" see, for example, Nathans, Beyond the Pale; Eugene M. Avrutin, Jews and the Imperial State: Identification Politics in Tsarist Russia (Ithaca, 2010). 
were usually treated as ethnographic material that could be turned into either Poles or Russians, in the late imperial period no one had any doubt that the modern Lithuanian nation was in the process of forming.

In the right-wing part of the Lithuanian national movement, the Poles took the most important position in the hierarchy of enemies, so it is no wonder that Lithuanian activists from this stream searched for allies among the empire's ruling elite. It was with such an intention in mind that Jonas Basanavičius, one of the leaders of Lithuanian nationalism, published antiPolish articles in 1883 in the newspaper Novoe vremia. In 1884, Jonas Šliūpas gave the governor-general of Warsaw a note with the Lithuanians' demands, and in 1911, Basanavičius and another two right-wing figures, Antanas Smetona and Mečislovas Davainis-Silvestraitis, entered into negotiations with Russian right-wingers regarding the formation of a joint anti-Polish front. ${ }^{47}$ It is not difficult to understand this kind of logic from Lithuanian activists, not only because they needed allies in the fight with the much stronger Polish national movement, but also because some tsarist officials, who incidentally spoke about this from time to time, believed the Russian government would benefit from supporting the Lithuanians against the Poles. For example, in 1904, when the ban on printing Lithuanian publications using the traditional (Latin and Gothic) script was lifted, the liberalization of the regime began, and Lithuanians started to submit requests to publish their own newspapers, Alexey Kharuzin, the chief of the Vil'na governor-general's office (1902-4), wondered whether permission should not be given to publish two Lithuanian newspapers, one of a Catholic orientation, and one a liberal newspaper. The claim was that there was no need for a Polish newspaper as there were no Polish common people (peasants) in this region-thus a Polish newspaper for the peasantry should not be allowed-while the "educated class" did not need one. ${ }^{48}$ Indeed, the first newspaper in the Lithuanian language started being published in Vil'na in December 1904, while after the rejection of numerous requests, the government allowed the publication of a Polish newspaper only six months later. ${ }^{49}$ An assembly of tsarist officials in St. Petersburg in 1914 discussed anti-Polish policy measures, as well as support for the Lithuanians: "If the government decided it was beneficial to be guided by the tried-and-tested 'divide and rule' method, it should support the development of the Lithuanian Catholic national identity." Only up to a certain degree, however: "But, of course, not to the harsh extent of national opposition that exists in the Baltic region between Latvians and Germans." ${ }^{\circ 0}$ However, in this case too it was not just that such measures were not implemented, but the discussion itself, as

47. J. Bkp [Jurgis Šaulys], “J. Šliupo pasiuntinystė Varšuvoje,” Varpas 3 (1904): 42-45; Lietuviu literatūros ir tautosakos institutas (The Institute of the Lithuanian Literature and Folklore), f. 1, b. 1843, 1.1 (Mečislovas Davainis Silvestraitis' letter to Jonas Basanavičius); Rimantas Miknys, Lietuvos demokratu partija 1902-1915 metais (Vilnius, 1995), 150-51.

48. Gosudarstvennyi Arkhiv Rossiiskoi Federatsii (GARF), f. 1729, op. 1, d. 1576, 1. 67-68 (Alexey Kharuzin's letter to Petr Sviatopolk-Mirskii, August 9, 1904)

49. Roman Jurkowski, “'Kurjer Litewski' w latach 1905-1907,” Kwartalnik Historii Prasy Polskiej 22 no. 1 (1983): 79-81. Yet, more research is needed in order to explain whether this delay was somehow related to nationality-policy reasons.

50. Zapadnye okrainy Rossiiskoi imperii, 388. 
we can see, was not presented as a strict recommendation but as a theoretical possibility. That is why they used the conditional tense. Nevertheless, the two main spheres where Lithuanians expected the imperial government's support in the fight against the Poles was with the Catholic Church and territorialadministrative division.

In the 1880s, Ivan Kakhanov, the governor-general of Vil'na (1884-93), put forward various measures against the domination of Poles in the region, also recommending that they no longer be accepted into Catholic seminaries, or at least setting a certain percentage (for example, 10 per cent), and regulating how many should be accepted. ${ }^{51}$ The government did not support this initiative, however, not only because it did not want to anger the Poles but also because it did not really have any reason for supporting the Lithuanians, who lived not just in the Russian Empire but in another state as well (Germany), where a movement already existed with the goal of "awakening the LithuanianSamogitian nationality [narodnost']." Ministry of Education officials noticed that graduates of peasant origin from these seminaries often harbored antiRussian sentiments, so that they were no better than the Poles. ${ }^{52}$

If in the 1890s some officials did not notice the Lithuanian national movement, in subsequent decades no official in the empire could allow himself to ignore it. One of the harshest arenas for the Polish-Lithuanian collision was the Catholic Church: conflicts developed in churches in the dioceses of Sejny and Vil'na regarding the language supplementary services would be conducted in. These conflicts sometimes became violent and Lithuanians started demanding that they should take charge of the Diocese of Vil'na. ${ }^{53}$ It could be that the first such conflicts over the language for Mass occurred at the end of 1889. In 1908, the governor of Suwałki even referred to these collisions between Poles and Lithuanians as chronic. ${ }^{54}$ On reading reports about these incidents by government representatives at various levels, we discover that

51. In the 1860s, a numerus clausus was introduced for Poles in Russian universities that at first was applied to Lithuanians as well, because they too were Catholics. However, in 1872 the Minister of Education Dmitrii Tolstoi, having received the emperor's permission, declared that this clause no longer had to apply to Lithuanians. See file LVIA, f. 567, ap. 27, b. 49 (Otnositel'no zhmudinam, okonchivshim kurs v gimnaziiakh, postupat' v Universitety na obshchikh osnovaniiakh). It is hard to say whether it had any practical significance or not. After spending a couple of decades in the military, in 1867 Kakhanov was appointed as the governor of the Piotrkow province and later became Vil'na's governor-general.

52. Vilma Žaltauskaitė, "Imperskaia vlast' i rimsko-katolicheskie dukhovnye seminarii posle 1863 g.,” Ab Imperio 4 (2012): 174-78.

53. Dariusz Szpoper, "Stosunki polsko-litewskie na przełomie XIX i XX wiekuwybrane aspekty,” in Jaroslav Volkonovski and Ryšard Gaidis, eds., Lietuvių-lenkų santykiai amžiu tèkmèje. Istorine atmintis (Vilnius, 2009), 128-33; Nerijus Ūdrènas, Book, Bread, Cross, and Whip: The Construction of Lithuanian Identity in Imperial Russia (PhD diss., Brandeis University, 2000), 426-51; Vytautas Merkys, Tautiniai santykiai Vilniaus vyskupijoje 1798-1918 m. (Vilnius, 2006), 332-77; Algimantas Katilius, "Pridètiniu pamaldų kalba Seinų vyskupijos bažnyčiose XIX a.-XX a. pradžia," in Algimantas Katilius. Ed., Vyskupo Antano Baranausko anketa dvarininkams (1898 m.), ed. (Vilnius, 2012), 11-58.

54. Archiwum Głównie Akt Dawnych, KWGG, 6478, karta (k.) 35 (Suwałki governor’s report for 1908). 
officials basically took on the role of impartial observers, whose main concern was to maintain public order. It is hard to find any specific episodes where one or another conflicting side actually received the government's support. In other situations, however, we can see the partiality of individual officials towards the Lithuanians.

Sometimes this partiality towards Lithuanians is evident in the governors' reports: "The Polish-Lithuanian antipathy that has formed over the course of history at a time when all we see are the ambitions of the Poles, which are completely incompatible with the foundations of Russia's statehood, must be used as a tool in the fight against Polish cravings. That is why granting a degree of support to the Lithuanians, a nation that is much less hostile and dangerous to Russia, is one of today's government policy objectives on the [empire's] peripheries." ${ }^{55}$ Likewise, in 1906, Konstantin Krshivitskii, the governor-general of Vil'na (1905-9), recommended taking a positive view of "the Lithuanian and Belarusian nationalities [narodnosti] awakening toward a conscious life, and to help propel their proper growth." ${ }^{56}$ In order for Lithuanians to be liberated from Polish influence, the government had to support their demand that the Vil'na Catholic bishop-suffragan be "one of the Lithuanian national priests, providing he shall be loyal." ${ }^{57}$ Krshivitskii's desire to support the Lithuanians was made even clearer when the imperial government started creating plans for suspending Edward von der Ropp, the politically active Bishop of Vil'na. Seeking to reduce Polish influence in the Northwest Region, the Vil'na governor-general suggested Ropp be replaced by a Lithuanian priest, Antanas Karosas or Kazimieras Prapuolenis. Both were described as priests loyal to the Russian Empire. Even though Krshivitskii did not detail Prapuolenis' political orientation, apart from referring to his loyalty to the empire and providing a brief description of his career when he put forward his candidacy, Krshivitskii surely must have known that Prapuolenis was one of the most ardent anti-Polish activists in the Lithuanian national movement. Later, Prapuolenis published a famous brochure in Polish entitled Polskie apostolstwo w Litwie: Szkic historyczny 1387-1912 (The Polish Apostleship in Lithuania: A Historical Essay, 1387-1912), in which he accused the Polish clergy of Polonizing Lithuanians. In promoting this kind of decision, the Vil'na governor-general even considered a form of social engineering, diverting the Lithuanian national movement along a "suitable channel," creating a "buffer," so as to reduce "pressure from the Polish side." However, he was not bold enough to send these ideas to St. Petersburg. ${ }^{58}$ At the same time, we should note that Krshivitskii had an instrumental understanding of the Polish-Lithuanian conflict and the government's possible support for Lithuanians. "The Polish-Lithuanian fight must play a large if not deciding role, as after the awakened self-determination of the Lithuanians, will the

55. RGIA, f. 1284, op. 194, 1907, d. 49, 1. 6 (Suwałki governor's report for 1906).

56. Up until becoming governor-general, Krshivitskii spent all his career in the military and even participated in the suppression of the 1863-1864 uprising in Poland and Lithuania.

57. RGIA, f. 821, op. 2, d. 73, 1. 45-46 (Report from the Vil'na governor general to P. Stolypin, August 20, 1906).

58. This part of the document was crossed out. 
Belarusians' [self-determination] awaken and become fired-up.” He would gladly have recommended a Belarusian priest; however, he could not find a suitable candidate. ${ }^{59}$ If this suggestion from the Vil'na governor-general was implemented, then naturally it would have to be treated as support for the Lithuanian national movement.

Although at first Piotr Stolypin, the Prime Minister and the minister of internal affairs, looked favorably on the idea of a Lithuanian Bishop of Vil'na, and St. Petersburg started to probe how the Holy See might react, he soon changed his mind. ${ }^{60}$ This was influenced not just by the Holy See's negative reaction but by Stolypin's own ethno-political calculations. In his view, the move would be "privileging" the Lithuanians, as they comprised only a fraction of the Catholics in the diocese (280,000 out of 1.3 million), which would "annoy" the Poles ${ }^{61}$ Besides, in Stolypin's opinion, the Lithuanians could not be trusted at all, because of their leaning towards "socialist teaching." At this point, the minister immediately recalled the situation in the Baltic provinces, "where a whole swathe of government measures directed at ensuring the autonomy of the Estonians and Latvians unfortunately led to the situation that has unfolded there now." In order to satisfy the Lithuanians' demands, the minister suggested appointing a Lithuanian to be bishop-suffragan. ${ }^{62}$

At the time, officials of the empire approved a memorandum that the Lithuanians sent to the Pope in which they complained about the policy of Polonization being pursued by the heads of the Vil'na Diocese. They issued foreign passports for a Lithuanian delegation to meet with the Pope; the Vil'na Catholic Curia did not permit the Lithuanian priests to depart, however. ${ }^{63}$ In the end, the empire's government and the Holy See reached a compromise, and the Pole Fr. Kazimierz Mikhalkevich became the temporary head of the diocese. Only a few years later, in agreeing with the policy of reducing Polish influence in the diocese, the governor-general of Vil'na highlighted the fact that it was not the Lithuanian language that should dominate, but the language that was spoken by the majority of inhabitants of the region, or Russian. ${ }^{64}$ At the beginning of the twentieth century, tsarist officials aspired towards a closer assimilation of Belarusians into the Russian nation. If there

59. LVIA, f. 378, Bendrasis skyrius (BS), 1903, b. 583, 1. 51-53 (Report from the Vil'na governor general to P. Stolypin, January 11, 1907).

60. LVIA, f. 378, BS, 1903, b. 583, 1. 57 (Official letter from the minister of internal affairs to Vil'na governor general, January 26, 1907).

61. The Vil'na Diocese covered the Vil'na and Grodna provinces.

62. LVIA, f. 378, BS, 1903, b. 583, 1. 58-59 (Secret letter from the minister of internal affairs to Vil'na governor general, May 5, 1907). The minister had in mind Estonian and, in particular, Latvian social radicalism that had been demonstrated during the period of the 1905 Revolution. The government's apprehensions over "annoying” the Poles were mentioned in a notice on this topic sent by the Department for Religious Affairs of Foreign Confessions under the Ministry of Internal Affairs (report from January 12, 1907, ibid., 1. 54). In his answer to these arguments given by the minister, the governor general also added that Lithuanians did not need to be feared, as they were incapable of assimilating other nationalities, but this did not change Stolypin's opinion.

63. Merkys, Tautiniai santykiai, 379-84.

64. RGIA, f. 821, op. 2, d. 79, 1. 26 (Official letter from Vil'na governor to Kharuzin, February 4, 1909). Someone added the following comment in handwriting in this spot-“at least in the Belarusian dialect." 
were ever any suggestions from officials to allow the use of the Belarusian dialect, then it was only as a measure deemed necessary in the early stages of socialization, whereas later on Russian had to be adopted as the primary language. ${ }^{65}$

Another sphere where the leaders of the Lithuanian national movement expected the government's support, as was mentioned, concerned territorialadministrative division. One of important points of the Lithuanian political agenda in the early twentieth century was the separation from the Vistula region of the part of the Suwałki province where Lithuanians made up the majority of the population, joining it to other "Lithuanian" provinces in the Northwest Region. From the late nineteenth century, various officials also started to discuss the implementation of such territorial-administrative reorganization projects. In 1898, Vitalii Trotskii, one the most ardent latenineteenth-century Russifiers and the governor-general of Vil'na (1897-1901), suggested bringing Suwałki province under the jurisdiction of the Vil'na governor-general on the grounds of military requirements, geography (the desire to "round off" the Vistula region), and the population's ethnic composition (the Suwałki province was home to Lithuanians who needed to be protected from Polonization). ${ }^{66}$ Another similar idea was born almost concurrently in St. Petersburg: the formation of a Lithuanian administrative compound by incorporating the Lithuanian territories of the Vil'na and Suwałki provinces into the Kovna province. But these projects were left unrealized. In rejecting Trotskii's initiative Alexander Imeretinskii, the governor-general of Warsaw (1897-1900) quoted various reasons: the reform would be difficult to implement in a technical sense, as the laws that were valid in the Kingdom of Poland in the nineteenth century were different from those in place in the rest of the empire, so that any reorganization would result in management problems; there were doubts as to whether changes to the Suwałki province's administrative jurisdiction would actually stop, or at least reduce, propaganda about "Polish national ideas and goals" in Lithuanian society; this kind of reform, in the opinion of Imeretinskii, would be of little benefit, because it would simply contribute to "strengthening Lithuanian-Samogitian separatism"; and, ultimately, being guided by ethnic criteria when defining administrative boundaries could have unfavorable outcomes regarding other "Russian state interests." "The government, artificially creating special ethnographic units and grouping administrative centers based on nationality, would only highlight the existence of separate nationalities at the state level, going against the tsar's orders to protect Russia's state interests." ${ }^{67}$

65. Kharuzin wondered whether at first it would be possible to publish a newspaper in the "Belarusian dialect," but later a "truly Russian" [istinno russkii] publication would have to appear: GARF, f. 1729, op. 1, d. 1576, 1. 68 (Kharuzin’s letter to Sviatopolk-Mirskii, August 9, 1904).

66. As a military man, Trotskii spend many decades in the eastern parts of the empire. He was also not known to propagate subtle nationality policy methods. For example, as governor-general he vehemently opposed proposals to lift the ban of Lithuanian writing in the Latin script.

67. Darius Staliūnas, "Territorialising Ethnicity in the Russian Empire? The Case of the Augustav/Suvalki Gubernia," Ab Imperio 3 (2011): 145-66. Such an attitude was 
Nonetheless, in the beginning of the twentieth century some tsarist officials showed support for the Lithuanian national movement in one particular sphere. During the period 1906-15, tsarist officials employed two different approaches regarding the operation of Lithuanian organizations. Just as the Department of Foreign Confessions, Piotr Verevkin, governor of Kovna (1904-12) and Vil'na (1912-15) provinces, tolerated activities of the Lithuanian Catholic "Saulè" (the Sun) society, including establishment of society's primary schools, because by allowing this, as he expected, the influence of the Poles decreased in Kovna province. ${ }^{68}$ Verevkin also believed, however, that the existence of such schools was only a temporary matter that was allowed until the establishment of a sufficient number of state-run schools. At the same time, Polish organizations were prohibited from opening schools in the Northwestern Region. Other influential officials from the Ministry of Internal Affairs and the Ministry of Education considered any cultural activities carried out by other nationalities, especially the establishment of Catholic schools, as destructive for the integrity of the empire. They viewed Lithuanian "separatism" as equally dangerous as Polish separatism, and therefore tried to close not only "Saulë"-run schools, but the organization itself, too. Despite these efforts, "Saulë" was not closed, although officials greatly hindered its functionality before WWI, and head of the organization-a priest named Konstantinas Olšauskas-was deported from Kovna just after the outbreak of the war. ${ }^{69}$ On the other hand, another Lithuanian Catholic organization, "Rytas" (the Dawn), which was established in Vil'na province in 1913, could not get permission to open its own schools, even though the same Verevkin hailed its establishment as an implement that should have protected Lithuanians from Polish influences. $^{70}$

There was another factor that stopped the imperial government from supporting Lithuanians, namely, the revolutionary stream was very strong within the Lithuanian national movement, especially during the period of the 1905 Revolution. In the second half of 1905, Russian officials and teachers were driven en masse out of ethnic, rural areas in Lithuania, while Lithuanian peasants organized petitions on a mass scale to demand national rights, as well as radical social and economic reforms. ${ }^{71}$ Thus, the social radicalism of the Lithuanian national movement created new obstacle for those tsarist

logical following Imeretinskii's intentions to cooperate with the part of the Polish society that accepted the political status quo: Malte Rolf, Imperiale Herrschaft im Weichselland: Das Königreich Polen im Russischen Imperium (1864-1915) (Berlin, 2015), 97.

68. Kharuzin, who was already mentioned in this article as the one suggesting a limited favor for Lithuanians against Poles, served as director of that department from 1908 to 1911, and later (till 1913) as a deputy minister of internal affairs.

69. Vida Pukienè, Lietuviu švietimo draugijos XX amžiaus pradžioje (1906-1915 metais) (Vilnius, 1994); files RGIA, f. 821, op. 128, d. 44 (Rimsko-katolicheskiia obshchestva Kovenskoi gubernii); RGIA, f. 733, op. 177, 1910 g., d. 273 (Uchebnye zavedeniia litovskago obshchestva "Saule," Sv. Zity i dr.); RGIA, f. 821, op. 128, d. 715 (Rimsko katolicheskiia obshchestva); LVIA, f. 567, op. 12, d. 10190 (Po khodatajstvu obshchestva "Solntse," o razreshenii onomu otkryvat' nachal'nye uchilishcha).

70. Jūratė Kuzmaitè, “Vilniaus 'Ryto’ lietuvių švietimo draugija,” in Iš lietuvių kultūros istorijos, vol. 8: Mokslo, kultūros ir švietimo draugijos (Vilnius, 1975), 125.

71. Antanas Tyla, 1905 m. revoliucija Lietuvos kaime (Vilnius, 1968). 
officials who were eager to support this non-dominant ethnic group. Exactly as in the Baltic provinces.

\section{Dilemmas of the Nationality Policy in the Baltic Provinces and Finland}

Much as some right-wing Lithuanian politicians asked for the government's support against the Poles in the late nineteenth and early twentieth centuries, similarly in the second half of the nineteenth century the leaders of the Young Latvians movement were also noted for their Russophilia: they hoped to reduce the influence of the Baltic Germans with the help of the imperial government. ${ }^{72}$ From the 1860 s until 1883, the imperial government's representatives in the Baltic provinces looked approvingly upon, for example, Latvians' public activities. In this way, officials hoped the influence of Baltic Germans in the region would be reduced, and as they considered Latvians (and Estonians) to be nothing more than a certain ethnographic element that could join any higher culture (German or Russian), such activities did not cause them any concern. Some more senior imperial officials did not avoid using the services of the Young Latvians. Krišjānis Valdemārs presented his suggestions for school reform in the Baltic provinces to the Ministry of Education, and he was entrusted with the task of compiling dictionaries. Yet, this cooperation between imperial government structures or Slavophiles on the one side, and the Young Latvians on the other should not imply that each side imagined the results of their cooperation in the same way. Young Latvians who spoke in favor of the extended use of the Russian language did so in seeking to reduce German influence, and to create better career prospects for Latvians, whereas, for example, Slavophiles, according to a Russian historian Evgenija Nazarova, sought the "Russification of Latvians." 73

Latvians (and Estonians) exploited some of the empire-wide reforms that were meant to modernize the state (for example, the city government reforms of 1877), and significantly ramped up their activities. From a Baltic German perspective, government policy in this period was indeed to support the Young Latvians' movement; however, the imperial government in the Baltic provinces was simply implementing some of its empire-wide reforms, understanding perfectly well, of course, that they would weaken Baltic German positions. It would be difficult to mention any particular government policy measure that discriminated against Baltic Germans and privileged Latvians or Estonians. Additionally, after 1884 we see a change in the imperial government's attitude towards the Latvian movement, where its spread came to be viewed unfavorably. A policy of so-called Russification commenced; note especially the introduction of Russian as the language of instruction at all levels of education in schools, as well as the stricter censorship of Latvian

72. Paulis Lazda, "The Phenomen of Russophilism in the Development of Latvian Nationalism in the $19^{\text {th }}$ Century," in Aleksander Loit , ed., National Movements in the Baltic Countries During the $19^{\text {th }}$ Century, (Stockholm, 1985), 129-35; Andrejs Plakans, The Latvians: A Short History (Stanford, 1995), 100-101.

73. Evgeniia Nazarova, "Slovari Krish'ianisa Valdemarsa," in Rossia i Baltiia, vol. 4: Chelovek i istoriia (Moscow, 2006), 55-76. 
publications and restrictions on the activities of Latvian societies. This serves as even greater evidence that not only was there no support for the Latvian movement, but that even the discussions of affirmative actions were no longer resumed (as it had been up until 1883). ${ }^{74}$ The agrarian revolution of 1905 in the Baltic provinces, which highlighted the social radicalism of the Estonian and especially the Latvian national movements, only further reduced the potential for applying a divide and rule policy.

At precisely the time when Russian officials stopped talking about possible support for the Young Latvians national movement, the governor-general in Finland, Fiodor Geiden (1881-97), pursued the idea that Fennomans were not dangerous to imperial rule. Geiden's agenda declared that "separatist" ideas in the Grand Duchy of Finland were being promoted only by the Swedish-speaking elite (the Svecomans), while the Finnish-speaking activists (the Fennomans) were loyal to the Romanov Empire. Thus, based on the suggestions of the governor-general of Finland, the tsarist government should fight the Svecomans and support the Fennomans. Geiden thought that the Finnish language was not and would never be equal to either the Russian or the Swedish languages, so the Fennomans were not seen as a threat to Russia's state interests. The Finnish historian Osmo Jussila writes that Geiden cooperated with Fennoman activists and supported them in various ways against the Svecomans. ${ }^{75}$ Nevertheless, it is difficult to find any really important episode when the tsarist government gave some practical advantage to the Fennomans over the Svecomans.

To sum up, it can be said that not only did a large part of Russia's officials treat the Poles as the empire's main enemy, but they also recognized the weakness of Russian potential on the empire's western periphery. Even though bureaucrats avoided acknowledging this fact, especially in public, specific actions illustrate this weakness: the imperial government never established a Russian university in the Northwest Region, while in the three "Lithuanian" provinces (Vil'na, Kovna, and Grodna) no zemstvos were ever founded. ${ }^{76}$ In both cases, this decision was made because of the fears of the tsarist officials that the Poles would take such institutions into their own hands. Therefore, we should not be surprised that, from time to time, officials of various ranks deliberated, along with other anti-Polish measures, on whether other weaker, non-dominant ethnic groups should be supported in order to weaken the influence of the Poles in the region. Understandably, more extensive discussions on this topic could only begin after the abolition of serfdom in 1861 . However, the existence of such deliberations did not yet mean that this kind of policy was actually implemented.

From the mid-nineteenth century, an "imperial mentality," like the one that dominated in the first half of the century when the empire's cultural variety was understood as its strength, was not only evident in the empire's

74. Kristine Wolfahrt, Der Rigaer Letten Verein und die lettische Nationalbewegung von 1868 bis 1905 (Marburg, 2006), 47-80.

75. Osmo Jussila, Velikoe kniazhetsvo finliandskoe, 1809-1917 (Helsinki, 2009), 481.

76. For more on this see Weeks, Nation and State, 331-51. 
bureaucracy, but increasingly officials who wanted to see that the Romanov domains be as culturally homogeneous as possible held greater influence. ${ }^{77}$ As noted earlier, the Russian mental map of the Northwest Region, sometimes in its entirety, was understood not just as part of the empire but as part of Russian national territory. In this kind of territory, the majority of officials who recognized the weakness of the Russian assimilation project could accept the temporary existence of a non-Russian cultural area, but by no means could they initiate support to strengthen non-Russian nationalisms. That is why it is no accident that the most evident case associated with Lithuanians that could be classified as a divide and rule policy occurred in the Kingdom of Poland. ${ }^{78}$

At the beginning of the twentieth century, especially during the 1905 Revolution, another reason arose for explaining why the empire's bureaucrats could not support the Lithuanians against the Poles. At the time, in the imagined "hierarchy of enemies" of at least some officials, especially the more conservative ones, it was no longer periphery elites (Poles in Lithuania and Belarus, and Germans in the Baltic provinces) who were considered as posing the greatest threat to the empire's regime, but the socialist movement. The upheavals of 1905 demonstrated to officials that the nobility on the periphery was less dangerous than the Estonian, Lithuanian, or Latvian national movements, which were so "infected" with the ideas of socialism. Similar trends can be seen in the Vistula region, where at the same time some tsarist officials turned to the Catholic Church as an ally of the empire, one that was associated with social stability. ${ }^{79}$ The empire's conservative ruling elite could hardly have accepted the nationalisms of the "peasant" nations as their allies.

Thus, by taking a more critical approach towards the rhetoric of the empire's officials, and by paying more attention to specific nationality policy measures taken by the imperial government, we can see that regardless of the great dynamics of officials' attitudes there were very few cases when some tsarist officials truly supported Lithuanians as a counterweight against Poles. At the same time, one can identify periods of time, for example, in the second half of the nineteenth century, when the conditions for the Polish cultural activities were much more favorable compared to the ones for Lithuanians. More generally, the policy of divide and rule was in principle not applied on empire's western periphery regarding other non-dominant ethnic groups either.

77. Karsten Brüggemann, "Das Baltikum im russischen Blick. Russland und sein Anspruch auf die baltischen Staaten in der Perspektive des 19. Jahrhunderts,” in Jörg Hackmann and Robert Schweitzer, eds., Norodsteuropa als Geschichtsregion. Beiträge des III. Internationalen Symposiums zur deustchen Kultur und Geschichte im europäischen Nordosten vom 20.-22. September 2001 in Tallinn (Estland), (Helsinki, Lübeck, 2006), 395; Karsten Brüggemann, "The Baltic Provinces and Russian Perceptions in Late Imperial Russia,” in Karsten Brüggemann and Bradley D. Woodworth, eds., Russia on the Baltic (Vienna, 2012), 119-22.

78. Further research might still find some specific cases when local officials had supported Lithuanian cultural activities while not giving the same advantages for Poles but that would not change the general conclusion that such a policy was a very rare exception.

79. Rolf, Imperiale Herrschaft im Weichselland, 179. 